\title{
Sinter forging of zirconia toughened alumina
}

\author{
Y. J. HE, A. J. A. WINNUBST, H. VERWEIJ, A. J. BURGGRAAF \\ University of Twente, Faculty of Chemical Technology, Laboratory for Inorganic Chemistry, \\ Materials Science and Catalysis, P.O. Box 217, 7500AE, Enschede, The Netherlands
}

Sinter forging experiments have been carried out on powder compacts of zirconia toughened alumina (ZTA) Ceramics Alumina- $15 \mathrm{wt} \%$ zirconia was prepared by a gel precipitation method and calcined at temperatures of 900 or $1100^{\circ} \mathrm{C}$. Full densification of ZTA ceramics was obtained within $15 \mathrm{~min}$ at $1400^{\circ} \mathrm{C}$ and $40 \mathrm{MPa}$. A homogeneous microstructure can be observed with an alumina grain size of $0.7 \mu \mathrm{m}$ and a zirconia grain size of $0.2 \mu \mathrm{m}$. Almost no textural evolution occurred in the microstructure. During sinter forging the densification behaviour of the compacts was improved by an effective shear strain, for which values of more than $100 \%$ could be obtained. As a result of the shear deformation the densification of ZTA in the $\alpha$ alumina phase stage shifted to lower temperature. During pressureless sintering the $\theta$ to $\alpha$ alumina transformation temperature was dependent of the preceding calcination temperature, while during sinter forging this phase transformation was independent of calcination temperature and took place at a lower temperature.

\section{Introduction}

The densification and the strength of sintered ceramics are often limited by processing defects. Such defects arise from inhomogeneities in the powder compact after green forming [1-6] or from different sintering in two-phase ceramic systems. It is known that very fine grained ceramic powders are difficult to obtain in the monodispersed state. In most cases crystallite clusters, such as aggregates and agglomerates, are found [7]. Non-uniform particle packing can occur if remainders of agglomerates are present during compaction. This may result in inhomogeneous densification during sintering. Inhomogeneous densification in its turn leads to transient stresses, causing cracklike pores or large voids [5]. These flaws do not disappear easily during pressureless sintering and consequently limit densification, microstructural evolution and ultimate temperatures required for densification [8]. Inhomogeneous densification can also occur due to the presence of different phases in the compact (e.g., $\mathrm{Al}_{2} \mathrm{O}_{3}$ and $\mathrm{ZrO}_{2}$ ).

Some pressure assisted sintering techniques, like hot isostatic pressing (HIP) $[3,9,10]$, hot pressing (HP) $[11,12]$ and sinter forging $[1,13-16]$, provide the opportunity to prevent the formation of, or to eliminate, such flaws, consequently enhancing the mechanical properties and the reliability of the final material. It has been experimentally demonstrated that the flaws can be eliminated when an effective shear strain of 0.60 is achieved in pure alumina $[1,16]$. In comparison with the three main types of pressure assisted sintering techniques mentioned above, sinter forging has obvious advantages in improving densification and effectively eliminating residual flaws, because large shear strains can be imposed on the material [1].
In sinter forging an uniaxial pressure is applied on the samples, without any lateral constraint. Finally, sinter forging can be used for near net shaping directly from the powder compact.

During sinter forging, ZTA powder compacts, containing transition $(\theta)$ alumina, show a strong improvement in densification prior to the phase transformation to $\alpha$ alumina. Therefore, sinter to full density at lower temperature is possible if compared with pressureless sintering [17]. The effect of calcination temperature on densification during pressureless sintering was investigated in [17], while the influence of powder calcination temperature on the behaviour of compact during sinter forging was not clear. The microstructural development of these powder compacts and its influence on densification at $\alpha$ alumina sintering stages during sinter forging, have not been indicated yet.

In this paper the relationship between calcination, densification and sinter forging is studied in detail. Two calcination temperatures are used. Finally, microstructural development during sinter forging is investigated and is compared with that during pressureless sintering.

\section{Experimental procedure}

Alumina-15 wt \% zirconia powders were prepared by the gel coprecipitation method. Preparation involves the hydrolysis in ammonia of an aluminium chloride (Merck, extra pure) and zirconium chloride (Merck, p.a.) solution. The hydrous gel was washed using water-ammonia mixtures in order to remove chlorides. Subsequently, the coprecipitated gel was washed with ethanol to remove free water. After that, the filtered gel was dried in air at $120^{\circ} \mathrm{C}$. More experi- 
mental details are described in [17]. The powders were calcined at 900 or $1100^{\circ} \mathrm{C}$ for $2 \mathrm{~h}$. All powders were isostatically cold-pressed at $50 \mathrm{MPa}$ in a large plastic tube. The compacts obtained were ground in a mortar in order to improve the flow behaviour of the powder, and were subsequently pressed uniaxially in a die at the same pressure into rectangular samples. Finally, these samples were isostatically cold-pressed at $400 \mathrm{MPa}$ and pressureless sintered or sinter forged in air.

Pressureless sintering was done in a Vecstar tube furnace. The heating and cooling rates were $2^{\circ} \mathrm{Cmin}^{-1}$. Sinter forging experiments were performed in static air using a uniaxial hot press equipment with silicon carbide heating elements and $\mathrm{SiC}$ pistons. A force transducer was mounted under the lower piston. Heating and loading were controlled by a Eurotherm Fics-11 controller. In order to improve the strength of the compacts prior to sinter forging, the green compacts were presintered at $1200^{\circ} \mathrm{C}$ for $15 \mathrm{~min}$. After presintering, the specimens were machined into cylindrical specimens of $8 \mathrm{~mm}$ height and $5 \mathrm{~mm}$ diameter. During sinter forging the samples were heated to $1150^{\circ} \mathrm{C}$ by $10^{\circ} \mathrm{C} \mathrm{min}^{-1}$ with an initial load of $5 \mathrm{MPa}$. The pressure was subsequently increased linearly to $40 \mathrm{MPa}$ in the temperature range of $1150-1200^{\circ} \mathrm{C}$ in 20 minutes. Finally, the samples were heated to 1400 or $1450^{\circ} \mathrm{C}$ at a rate of $2^{\circ} \mathrm{C} \mathrm{min}^{-1}$ and held at this temperature for $15 \mathrm{~min}$. While the load acting on the sample was kept constant, the uniaxial pressure changed because the dimension of the samples changed during sinter forging. The pressure values specified below are based on the initial dimensions.

Sinter forging experiments allow a simultaneous analysis of creep and densification. Densification and the shear strain (creep strain) are separated using the procedure given in [1]. The volume strain, $\varepsilon_{v}$, axial strain, $\varepsilon_{z}$, radial strain, $\varepsilon_{\mathrm{r}}$, and the effective shear strain, $\varepsilon_{\mathrm{e}}$, are given by the following relations

$$
\varepsilon_{\mathrm{v}}=\ln \frac{V}{V_{\mathrm{o}}}=\ln \frac{\rho_{\mathrm{o}}}{\rho} \quad \varepsilon_{\mathrm{r}}=\ln \frac{r}{r_{\mathrm{o}}} \quad \varepsilon_{\mathrm{z}}=\ln \frac{h}{h_{\mathrm{o}}}
$$

where $r_{\mathrm{o}}, h_{\mathrm{o}}, V_{\mathrm{o}}$ and $\rho_{\mathrm{o}}$ are the initial radius, height, volume and density of specimens, respectively, and $r$, $h, V$ and $\rho$ are the values of these parameters after the sinter forging experiment.

The shear strain (creep strain), $\varepsilon_{\mathrm{e}}$, is written as

$$
\varepsilon_{\mathrm{e}}=2 / 3\left|\varepsilon_{\mathrm{z}}-\varepsilon_{\mathrm{r}}\right|=\left|\varepsilon_{\mathrm{z}}-\left(\varepsilon_{\mathrm{v}} / 3\right)\right|
$$

To analyse the densification process, the compacts were heated to the desired temperature at $2^{\circ} \mathrm{C} \mathrm{min}^{-1}$ and immediately cooled afterwards. Densities were measured by the Archimedes technique in mercury. Some experiments for analysis of axial strains were performed. In these experiments, the compacts were presintered at $900^{\circ} \mathrm{C}$; the sinter forging started at a temperature of $950^{\circ} \mathrm{C}$, while the maximum pressure of $40 \mathrm{MPa}$ was achieved at $1000^{\circ} \mathrm{C}$ with heating and cooling rates of $2{ }^{\circ} \mathrm{C} \mathrm{min}^{-1}$.

The fraction of tetragonal and monoclinic phase of ZTA powders was measured by means of X-ray dif- fraction (XRD) analysis [18], using $\mathrm{CuK}_{\alpha}$ radiation in a Philips PW1710 X-ray diffractometer. The microstructure of polished-thermally etched surfaces was analysed by a Jeol JSM-35CT scanning electron microscope (SEM). The microstructure development after sinter forging was also examined by a Jeol $200 \mathrm{CT}$ transmission electron microscope (TEM) on ion thinned samples. The grain sizes of sintered ceramics were measured by the linear intercept method [19] from SEM pictures. Specific surface areas, $S_{\mathrm{BET}}$, of the powders were determined by the Brunauer EmmettTeller BET method. The pore size distribution was examined at $77 \mathrm{~K}$ with nitrogen adsorption-desorption isotherms using a Micromeritics ASAP 2400 system. Pore sizes larger than $15 \mathrm{~nm}$ were determined by mercury-intrusion porosimetry using a Carlo Erba Series 200 porosimeter.

\section{Results and discussion}

The characteristics of the alumina- $15 \mathrm{wt} \%$ zirconia powders are given in Table I. All coprecipitated powders were fully crystallized after calcination at 900 and $1100^{\circ} \mathrm{C}$, in agreement with [17]. The alumina was present in the transition $(\theta)$ state. Most of the zirconia phase in the undoped zirconia-alumina powders is monoclinic at room temperature. Irregular platelet $\theta$ alumina aggregates are present in the powder calcined at $900^{\circ} \mathrm{C}$, whereas after calcination at $1100^{\circ} \mathrm{C}$ the aggregates are already completely densified and recrystallized into new $\theta$ alumina "single" crystals. The differences in morphology at the calcination temperatures of 900 and $1100^{\circ} \mathrm{C}$ are discussed in detail in [17].

TA B LE I Characteristics of zirconia toughened alumina powders

\begin{tabular}{rlll}
\hline $\begin{array}{l}T_{\text {calc }}{ }^{\mathrm{a}} \\
\left({ }^{\circ} \mathrm{C}\right)\end{array}$ & Alumina phase & Zirconia phase & $\begin{array}{l}S_{\mathrm{BET}} \\
\left(\mathrm{m}^{2} \mathrm{~g}^{-1}\right)\end{array}$ \\
\hline 900 & $\theta$ & $73 \% \mathrm{~m}^{\mathrm{b}}$ & 92 \\
1100 & $\theta$ & $73 \% \mathrm{~m}^{\mathrm{b}}$ & 45 \\
\hline
\end{tabular}

${ }^{\mathrm{a}} T_{\text {cale }}$, temperature of calcination.

${ }^{\mathrm{b}} \mathrm{m}$, monoclinic.

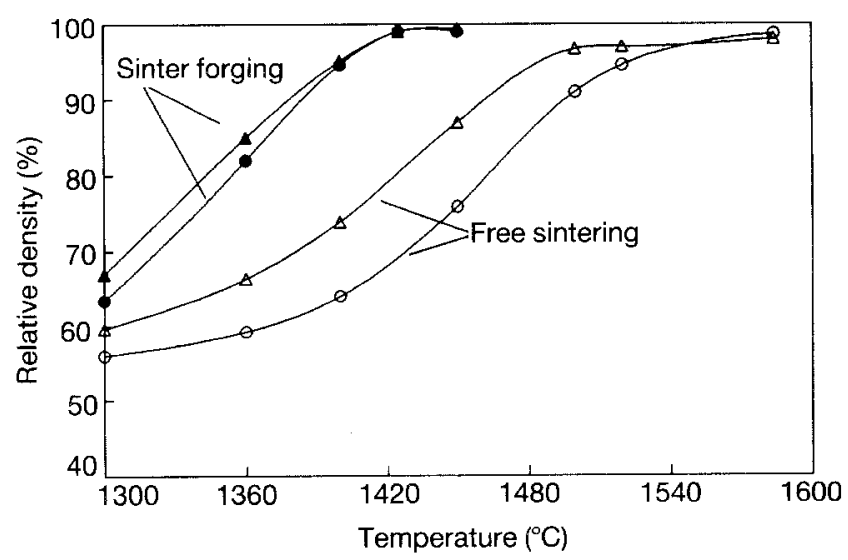

Figure I Densification behaviour during pressureless sintering and sinter forging: $(\bullet, O)$ calcined at $900^{\circ} \mathrm{C} ;(\Delta, \triangle)$ calcined at $1100^{\circ} \mathrm{C}$. Dwell time at each point is $0 \mathrm{~h}$. 


\begin{tabular}{|c|c|c|c|c|c|}
\hline \multirow{2}{*}{$\begin{array}{l}T_{\text {calc }} \\
\left({ }^{\circ} \mathrm{C}\right)\end{array}$} & \multirow{2}{*}{$\begin{array}{l}\text { Pressure } \\
(\mathrm{MPa})\end{array}$} & \multicolumn{2}{|l|}{ Sinter } & \multirow{2}{*}{$\begin{array}{l}\text { Shear strain } \\
\varepsilon_{\mathrm{e}}\end{array}$} & \multirow{2}{*}{$\begin{array}{l}\text { Relative density } \\
(\%)\end{array}$} \\
\hline & & Temperature & Time (min) & & \\
\hline 900 & 0 & 1450 & 15 & 0.00 & 78 \\
\hline 900 & 0 & 1450 & 120 & 0.00 & 91 \\
\hline 900 & 0 & 1500 & 120 & 0.00 & 97 \\
\hline 900 & 40 & 1400 & 15 & 0.79 & 99 \\
\hline 900 & 40 & 1450 & 15 & 1.13 & 100 \\
\hline 1100 & 0 & 1450 & 15 & 0.00 & 87 \\
\hline 1100 & 0 & 1450 & 120 & 0.00 & 98 \\
\hline 1100 & 0 & 1500 & 120 & 0.00 & 98 \\
\hline 1100 & 40 & 1400 & 15 & 0.80 & $99+$ \\
\hline 1100 & 40 & 1450 & 15 & 1.07 & 100 \\
\hline
\end{tabular}

\subsection{Sinter forging behaviour}

Densification data of ZTA compacts during sinter forging and pressureless sintering are presented in Fig. 1. A comparison of the densification behaviour of ZTA ceramics for both pressureless sintering and sinter forging is also given in Table II. The results in Fig. 1 and Table II show that during pressureless sintering, that densification as a function of temperature of ZTA compact calcined at $1100{ }^{\circ} \mathrm{C}$ is obviously faster than that of a powder compact calcined at $900^{\circ} \mathrm{C}$. This influence of calcination temperature is not observed for sinter forging, contrary to the situation during pressureless sintering. In order to investigate this phenomenon, pore morphology development during sintering was examined.

In Fig. 2 a nitrogen adsorption-desorption isotherm is given for a powder calcined at $900{ }^{\circ} \mathrm{C}$ and isostatically pressed at $400 \mathrm{MPa}$. From this figure it can be seen that two hysteresis loops are present. The hysteresis loop in the relative pressure range from 0.6 to 0.85 is observed only in compacts of powders calcined at $900^{\circ} \mathrm{C}$, while the hysteresis loop in the range from 0.9 to 1.0 is found in compacts of both powders. According to De Boer [20] the hysteresis loop observed in the relative pressure range of $0.6-0.85$ can be built up from a type B hysteresis loop and an isotherm of type II. Such a combination is expected for a capillary system of open slit-shaped pores together with wedge-shaped capillaries with a closed edge at the narrower side. Most transition alumina particles have a plate or rod like structure, and therefore the pore structure is ascribed to pores between $\theta$ alumina crystallites and partly sintered crystallites, together forming strong aggregates [17]. From the volume of nitrogen adsorbed in the relative pressure range of $0.6-0.85$ a relative aggregate density of $65 \%$ was calculated, while the individual $\theta$ alumina crystallites have a platelet thickness of $6 \mathrm{~nm}$ as determined by $\mathrm{X}$-ray line broadening analysis and from TEM pictures [17].

After calcination at $1100^{\circ} \mathrm{C}$ these slit-shaped pores are not observed any more, and in these cases a $\theta$ alumina crystallite size of $35 \mathrm{~nm}$ was found [17]. It can be concluded, therefore, that after calcination at $1100^{\circ} \mathrm{C}$ the internal aggregate structure is completely densified and recrystallized to new $\theta$ alumina "single" crystals.

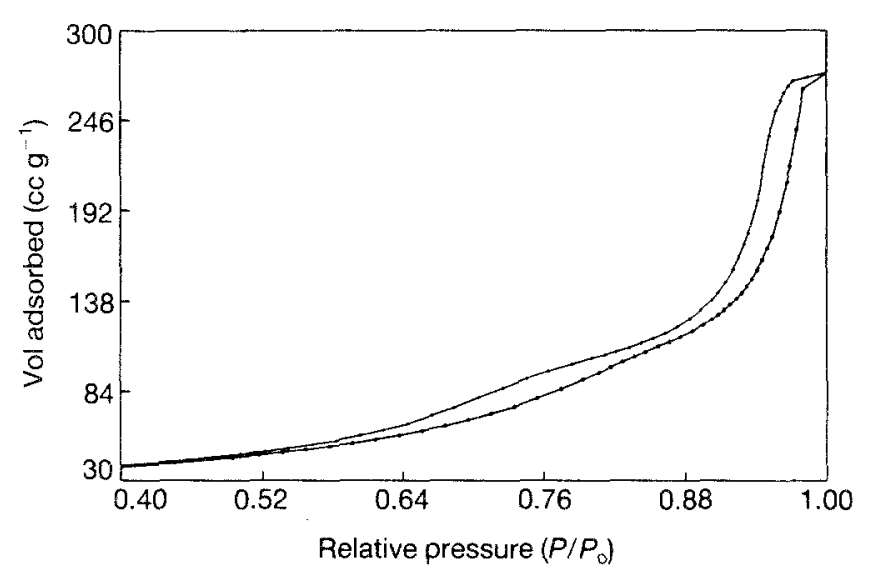

Figure 2 Nitrogen adsorption-desorption isotherm of a powder calcined at $900^{\circ} \mathrm{C}$ and isostatically pressed at $400 \mathrm{MPa}$.

The hysteresis loop in the relative pressure range of $0.9-1.0$, as observed for both powder compacts, is of so-called "A" type [20]. This type of hysteresis loop corresponds to tubular capillaries with slightly widened parts. These pores represent the pores between the spherical like (dense or porous) aggregates.

Den Exter et al. [17] observed that in the compact of powder calcined at $900^{\circ} \mathrm{C}$, a broad tail of small pores persist during the transformation to the $\alpha$ alumina phase. Whereas the compact of powder calcined at $1100^{\circ} \mathrm{C}$ shows only uniform (cylindrical) pores, with a narrow size distribution after the phase transformation to $\alpha$ alumina. This absence of small pores after the phase transformation is held responsible for the lower temperature necessary for the pressureless sintering densification of ZTA when compared to compacts calcined at lower temperatures.

During sinter forging these small pores in the compact calcined at $900^{\circ} \mathrm{C}$ are not present any more after the $\theta$ to $\alpha$ alumina phase transformation (see Fig. 3). The pore size distribution of the compacts calcined at 900 and $1100^{\circ} \mathrm{C}$ is approximately the same. So, sinter forging has a significant influence on the microstructure development of particle aggregates. The extra pressure during sinter forging results in shear deformation and internal reorganization of particles in ZTA compact. The shear deformation and the rearrangement provide an opportunity to eliminate 


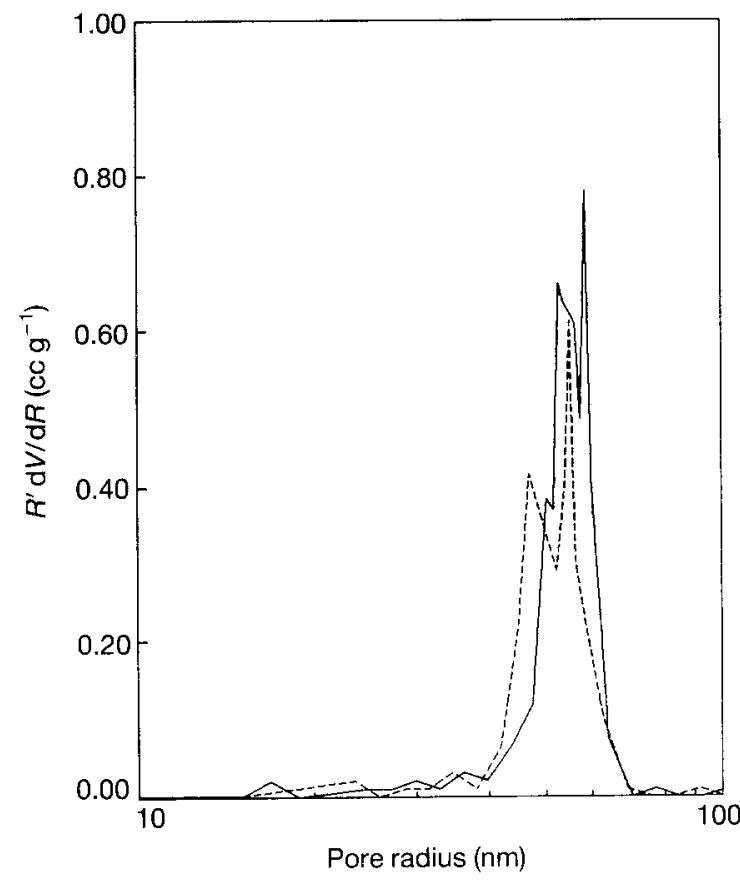

Figure 3 Pore size distribution of powder compacts during sinter forging after phase transformation at $1250^{\circ} \mathrm{C}$, calcined at $900^{\circ} \mathrm{C}$ (solid line) and $1100^{\circ} \mathrm{C}$ (dotted line).

small intra-aggregate pores and transfer them to larger inter-aggregate pores in the compact calcined at $900^{\circ} \mathrm{C}$ prior to $\theta$ to $\alpha$ alumina phase transformation, obviously resulting in a similar pore morphology for compacts calcined at 900 and $1100^{\circ} \mathrm{C}$ after the $\theta$ to $\alpha$ alumina transformation. A tendency of identical densification behaviour is expected in the $\alpha$ alumina sintering stage for both compacts during sinter forging.

In Fig. 4a typical axial strain curves as a function of sintering temperature in the compacts calcined at 900 and $1100^{\circ} \mathrm{C}$ are given. No difference in the axial strain is observed in both compacts calcined at 900 and $1100^{\circ} \mathrm{C}$. At about $1216^{\circ} \mathrm{C}$, the axial strain rate drastically decreases (Fig, $4 \mathrm{~b}$ ), after which the axial strain rate increases again with increasing temperature. XRD analyses showed that this temperature resembles the phase transformation temperature from $\theta$ to $\alpha$ alumina. Just after the $\theta$ to $\alpha$ alumina phase transformation, almost no axial strain is observed. The axial strain increases again after this phase transformation. This phenomenon was also found in the densification curves of pressureless sintered compacts, where a dramatic decrease in axial linear shrinkage was observed just after phase transformation [17]. For both compacts calcined at 900 and $1100^{\circ} \mathrm{C}$, respectively, the $\theta$ to $\alpha$ alumina phase transformation takes place at almost the same temperature during sinter forging. So sinter forging behaviour in the ZTA materials is independent of calcination temperatures. This is due to morphological developments in the first sinter stage. The results observed above confirm the identical sinter forging behaviour of both compacts again. The applied compressive stress encourages transformation at a lower temperature since stress increases the transformation kinetics. The same result
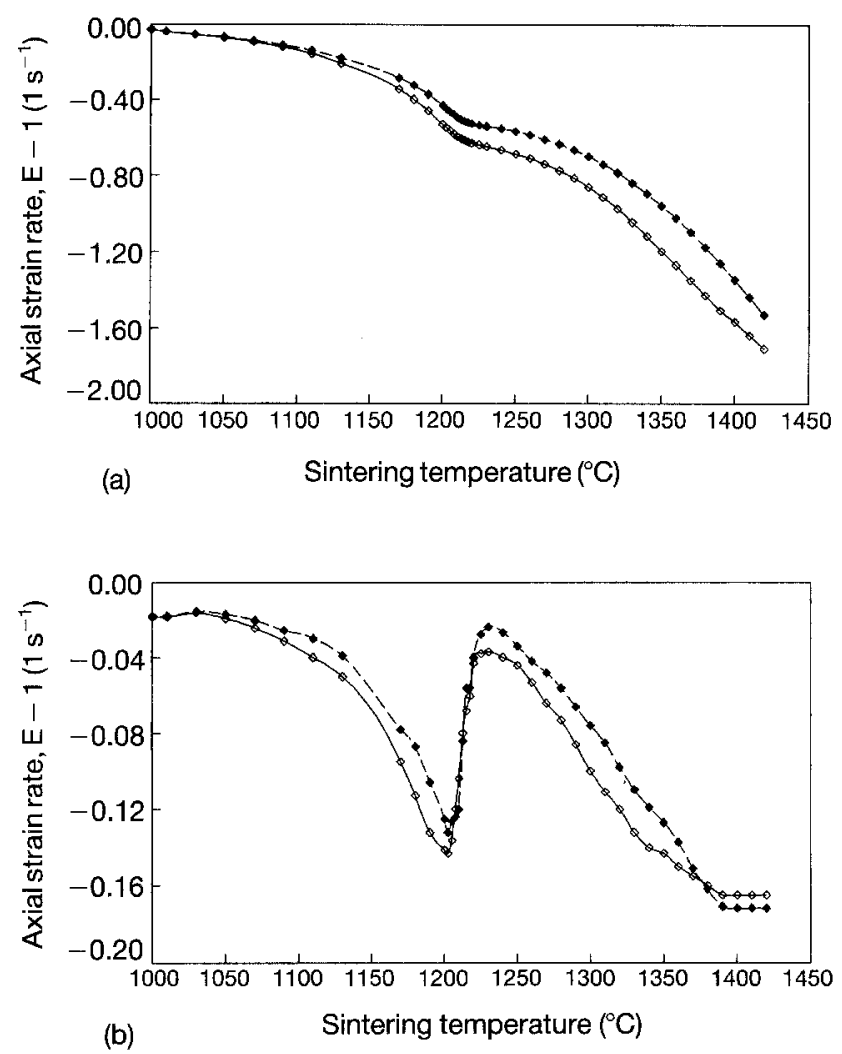

Figure 4 Typical axial strain (a) and axial strain rate (b) curves of zirconia toughened alumina calcined at $900^{\circ} \mathrm{C}(\diamond)$ and $1100^{\circ} \mathrm{C}(\diamond)$. Heating rate is $2^{\circ} \mathrm{C} \mathrm{min}^{-1}$ during sinter forging.

is obtained by Hague and Mayo [21] in $\mathrm{TiO}_{2}$ phase transformation from anatase to rutile.

Fig. 1 and Table II also show that sinter forging has shifted the densification of ZTA compacts to lower temperature at $\alpha$ alumina stage. The same dense ZTA by means of pressureless sintering can be obtained only at temperatures at least $100^{\circ} \mathrm{C}$ higher than that by sinter forging. After sinter forging at $1400^{\circ} \mathrm{C}$ for $15 \mathrm{~min}$, a dense ZTA ceramic ( $99 \%$ density) is obtained. Prolonged hot pressing results in an increase in shear strain, which is caused by pure creep. So, the hot forging state starts at this point. After pressureless sintering at $1450{ }^{\circ} \mathrm{C}$ for $15 \mathrm{~min}$, the densities of ZTA compacts calcined at 900 and $1100^{\circ} \mathrm{C}$, are only 78 and $87 \%$, respectively. A temperature of $1450-1500^{\circ} \mathrm{C}$ for at least $2 \mathrm{~h}$ is necessary to obtain high density ZTA materials under pressureless sintering. These results clearly indicate that sinter forging has a significant influence on sintering behaviour and gives a strong improvement in densification. The large shear strain obtained during sinter forging (see Table II) is an important factor in the densification of ZTA ceramics. Fig. 5 illustrates the densification behaviour with or without shear strain. It can be seen that the volume strain, $\varepsilon_{\mathrm{v}}$, which represents densification (see Equation 1), increases as a function of sinter temperature when a shear strain, $\varepsilon_{\mathrm{e}}$, is present during sinter forging. The effect of sinter forging on densification is due to extra pressure and shear strain in the sintering process. These will be discussed now.

The conventional sinter process is divided into three stages: neck formation in the first stage, pore shrin- 


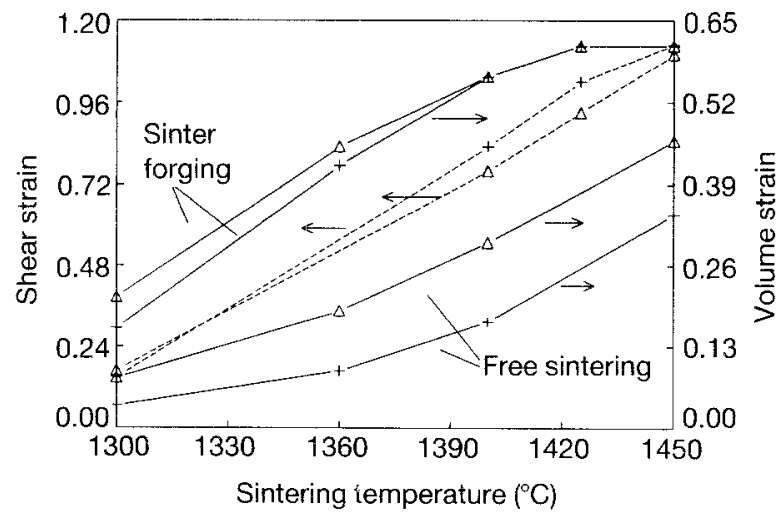

Figure 5 Shear strain $(--)$ ) and volume strain $(-)$ curves during sinter forging at $40 \mathrm{MPa}:(\triangle)$ calcined at $1100^{\circ} \mathrm{C} ;(+)$ calcined at $900^{\circ} \mathrm{C}$.

kage and densification in the second stage, and grain growth in the final stage. In the first stage the extra pressure acts on the compacts during densification of the $\theta$ alumina matrix. There is a strong rearrangement of the particles, resulting in an even more uniform pore size distribution after phase transformation compared with pressureless sintering. This is also identified by the pore size distribution given in Fig. 3 which is significantly different from the results of pressureless sintering [17]. Also more contact points between particles were formed during this process. Moreover local tensile stresses (back stress effect), due to inhomogeneous sintering, result in a locally decreased sinter pressure. Application of compressive stresses compensate these effects as will be discussed below. In this way more "necks" formed in an early stage and compensation of a locally decreased sinter pressure result in densification at lower temperatures than for normal sintering without the extra pressure used. However, the value of the shear strain is small at this moment, so the effect of shear strain on densification (Fig. 1, before $1300^{\circ} \mathrm{C}$ ) is smaller than in later sintering stages (after $1300^{\circ} \mathrm{C}$ ). Therefore, in the first sintering stage the application of an external pressure probably acts as an extra driving force to improve densification, based on the mechanism of interface reaction controlled grain boundary diffusion [22].

Sinter forging has an important influence on the pore shrinkage stage too (Fig. 1, above $1300^{\circ} \mathrm{C}$ ). Shear strain is an important factor contributing to densification of ZTA materials. According to [1] the large pores in the compact are flattened at this stage and disintegrate into small pores by shear strain. The flattened pores and the small pores are removed easily during the sintering process, as shown by Venkatachari and Raj [1]. In this pore shrinkage stage the densification rate is increased by a shear mechanism with interface reaction controlled grain boundary sliding $[1,14]$.

The sintering of ZTA materials is inhibited not only by pores in the compacts but also by processing flaws due to aggregates or agglomerates. Actual random packing of the powder particles in the green compacts due to the presence of aggregates or remainders of agglomerates can induce differential shrinkage. Areas

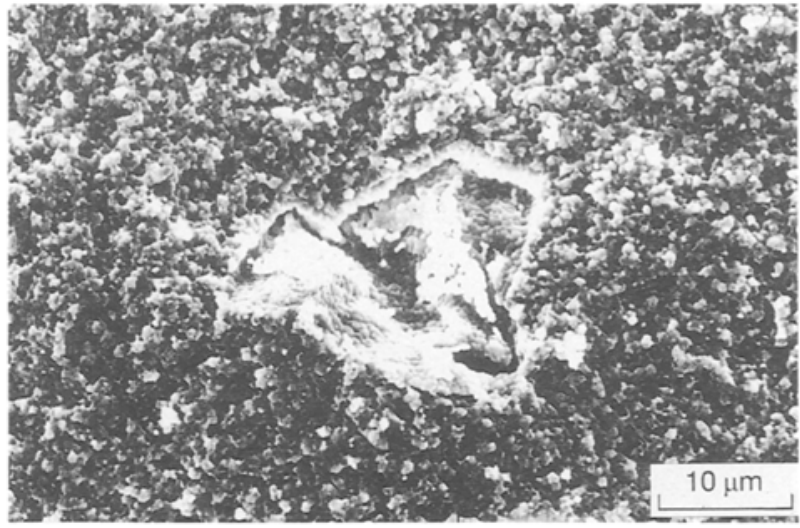

Figure 6 A cracklike defect on the fracture surface of a ZTA sample after pressureless sintering at $1500^{\circ} \mathrm{C}$ for $2 \mathrm{~h}$.

of high packing density have a higher sinter rate than the less dense parts. This process may cause internal stresses, resulting in the development of flaws at the second sintering stage and in a decreased local sinter pressure. These processing flaws are very difficult to remove. Fig. 6 shows an example of a large flaw, which has a negative influence on mechanical properties of ZTA materials [23]. During sinter forging, the shear deformations not only induce a uniform pore size distribution by means of particle rearrangement in the first sinter stage, but can also be effective to remove internal stresses due to inhomogeneous densification. As a result, the formation of process flaws is limited and an increase in density is observed. In the present paper, an effective shear strain (Fig. 5) of more than 0.8 was obtained at $40 \mathrm{MPa}$ at temperatures greater than $1400^{\circ} \mathrm{C}$. According to the literature [1], an effective shear strain of at least 0.6 is needed for eliminating process flaws and closing spherical pores at intermediate shear strain. Mechanical measurements on these samples show that strength and toughness increase by a factor of 1.5-2 if these ZTA samples are submitted to sinter forging treatment [23].

\subsection{Microstructure after sinter forging}

The microstructure of compacts observed by SEM after sinter forging at 1400 and $1450^{\circ} \mathrm{C}$ for $15 \mathrm{~min}$ are shown in Fig. 7. As can be seen from these SEM photographs the zirconia grains, which are the smaller and slightly lighter grains, are homogeneously dispersed in the alumina matrix. A few zirconia grains are located at the boundary of the alumina grain, most of them are present at triple junctions. After sinter forging at $1450^{\circ} \mathrm{C}$ for $15 \mathrm{~min}$, the mean grain size of alumina is $0.8 \mu \mathrm{m}$ and the mean grain size of zirconia is $0.3 \mu \mathrm{m}$. No difference in the microstructure of compacts between calcination at 900 and $1100^{\circ} \mathrm{C}$ is found. Somewhat smaller grain sizes, with a alumina grain size of $0.7 \mu \mathrm{m}$ and a zirconia grain size of $0.2 \mu \mathrm{m}$, are obtained after sinter forging at $1400^{\circ} \mathrm{C}$ for $15 \mathrm{~min}$ with full density.

In order to examine the influence of shear deformation on microstructure, such as preferential orientation during grain growth, the sinter forged specimens were cut both parallel and perpendicular to the 

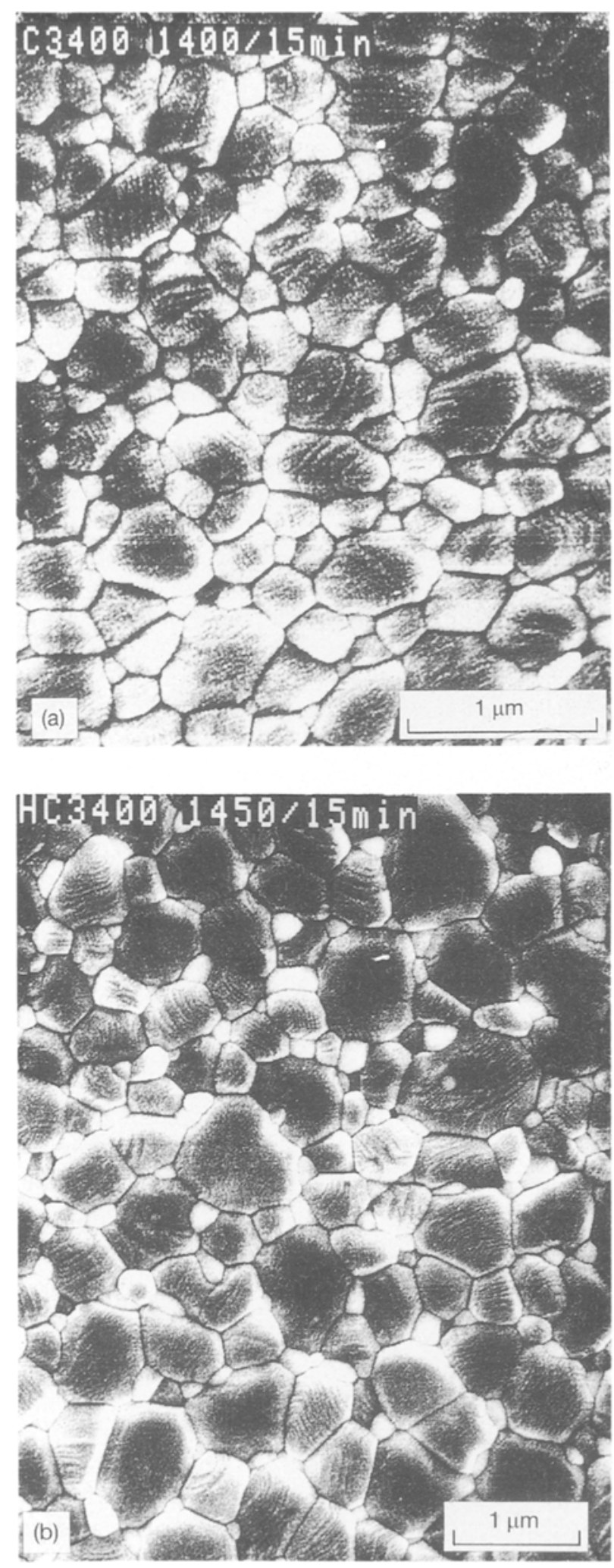

Figure 7 Microstructure of the compacts after sinter forging (a) at $1400^{\circ} \mathrm{C}$ for $15 \mathrm{~min}$, and (b) at $1450^{\circ} \mathrm{C}$ for $15 \mathrm{~min}$ : applied pressure, $40 \mathrm{MPa}$.

forging axis. The microstructure has been investigated by SEM and TEM. No textural development resulting in preferential orientation or shape changes is observed from SEM photographs of sinter forged specimens in Fig 7. The same conclusion is drawn from the TEM photograph of Fig. 8a. A few alumina grains are slightly elongated, however, after sinter forging at
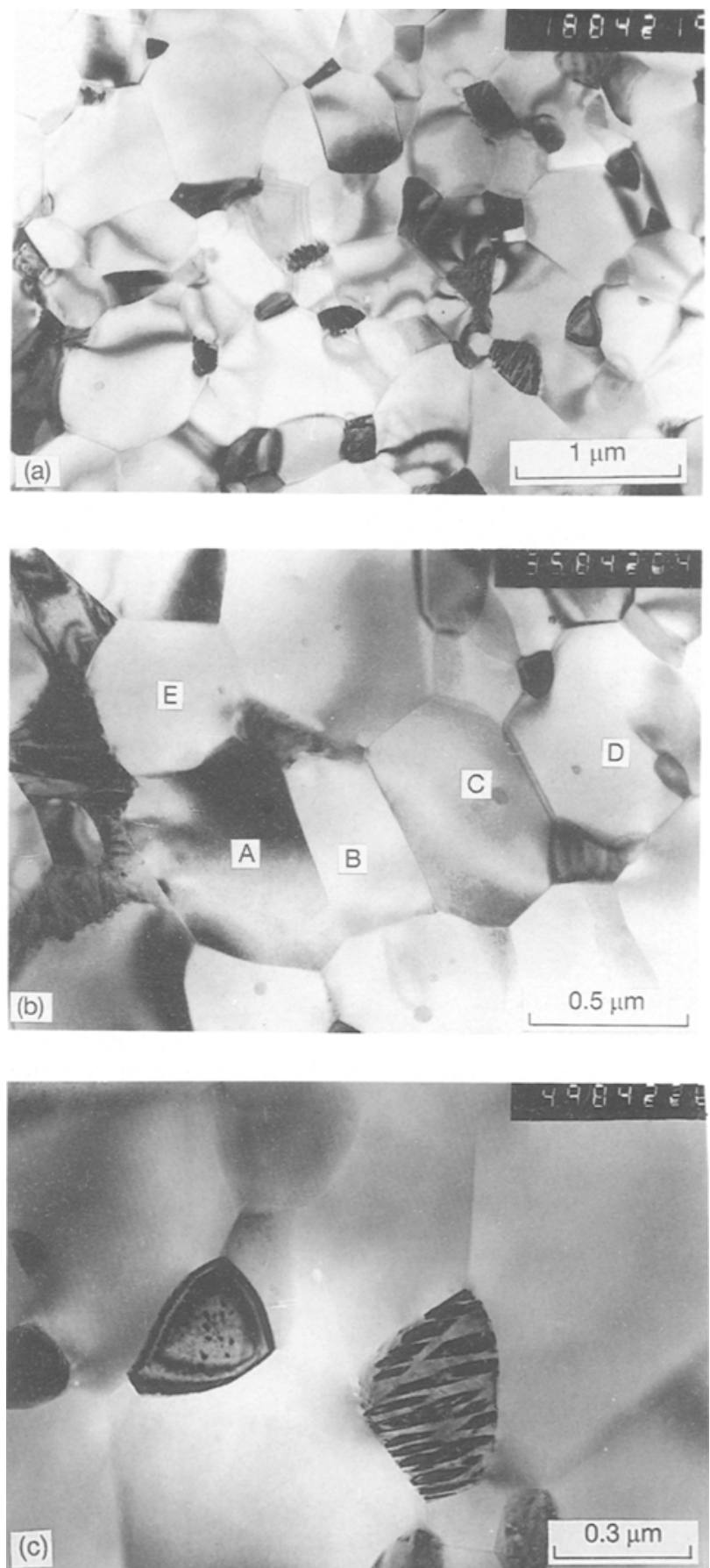

Figure 8 Transmission electron microscope of ZTA ceramics calcined at $1100^{\circ} \mathrm{C}$ after sinter forging at $1450^{\circ} \mathrm{C}$ for $15 \mathrm{~min}$ : (a) no obvious textural development, (b) few alumina grain elongations (see grains A, B and C) and alumina grains without any elongation (see grains $D$ and $E$ ), and (c) transformed and stable tetragonal zirconia in sinter forged ZTA materials.

$1450^{\circ} \mathrm{C}$ for $15 \mathrm{~min}$ as shown in the TEM picture of Fig. 8b. Contrary to this observation in $\mathrm{Al}_{2} \mathrm{O}_{3}-\mathrm{ZrO}_{2}$ composites, in the literature strong textures have been reported for pure alumina produced by forging deformation $[24,25]$, which is attributed to a combination of dislocation slip and recrystallization [25]. Kellett and Lange [13] showed that during deformation textural morphology can also appear in $\mathrm{Al}_{2} \mathrm{O}_{3}-\mathrm{ZrO}_{2}$ composite materials. $\mathrm{Ma}$ and Bowman [25] showed that textural development in alumina during compressive deformation is dependent on dopant addition, impurities, grain shape, temperature and strain 
rate effects. The discrepancy between our results and Kellett et al.'s [13] is ascribed to impurities (glass phase) and temperature. In the materials used in the experiments of Kellett et al. a certain amount of glass phases (about 760 p.p.m) was present at the junctions of three grains while a high forging temperature $\left(1600^{\circ} \mathrm{C}\right)$ was used. No texture is expected due to less contaminates in the materials used in our work or due to sinter forging taking place at a lower temperature (at $1450^{\circ} \mathrm{C}$ ), although a large shear strain of more than $100 \%$ is achieved.

It is argued that the presence of zirconia suppresses alumina grain growth to an elongated particle morphology. This is supported by the fact that some alumina grains not surrounded by zirconia grains show elongation, for example: alumina grains A, B and $\mathrm{C}$ in Fig. 8b. Alumina grains $\mathrm{D}$ and $\mathrm{E}$ in Fig. 8b, which are homogeneously surrounded by several zirconia grains, do not show any elongation. So, it is clearly observed that $\mathrm{ZrO}_{2}$ inhibits alumina grain elongation. The effect of zirconia on reduction of alumina grain elongation during sinter forging is less if a glassy phase exists or when zirconia is not well dispersed in the alumina matrix.

Fig. 8c shows transformed (monoclinic) and metastable tetragonal zirconia in the alumina matrix after sinter forging deformation at $1450^{\circ} \mathrm{C}$ for $15 \mathrm{~min}$. The twinned structure of the monoclinic crystals is clearly visible.

As has been discussed before, shear deformation can eliminate the flaws and close the pores in ZTA bulk. The pores at the surface (in contact with SiC plates) will hardly close during sinter forging because of tensile forces acting at the interface of $\mathrm{SiC}$ piston plates and ZTA compact. A SEM micrograph (Fig. 9) of the thermally etched surface area in contact with the $\mathrm{SiC}$ plate shows irregularly shaped pores and some pores linked together. The porosity on the surface is about $10 \%$. Nevertheless, the density of sinter forged compact is about $99 \%$. The same structure was observed also by Tsukuma and Shimaoa in hot isostatic pressing studies of yttria-partially-stabilized zirconia (Y-PSZ ceramics) [26]. The porous surface layer is about $40 \mu \mathrm{m}$ thick observed from a SEM picture of the fracture surface (Fig. 10). Below the surface layer at

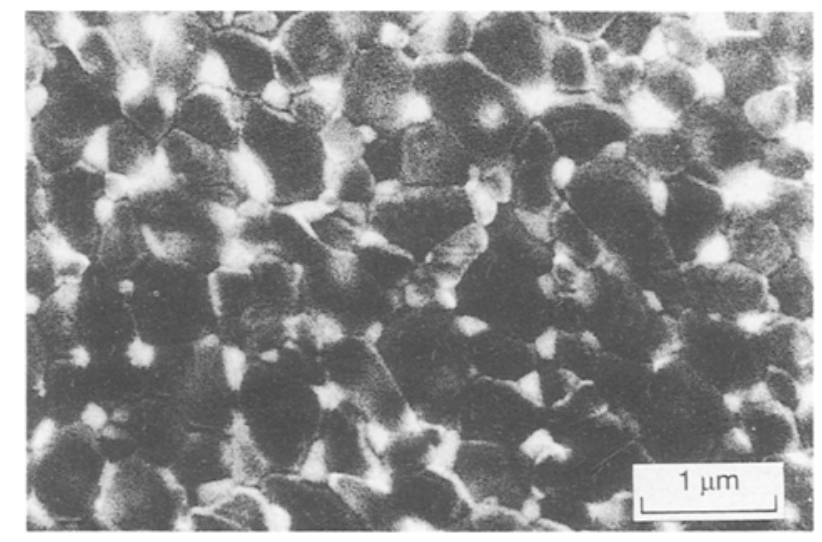

Figure 9 Opened pores on the surface contacted with $\mathrm{SiC}$ plate in as-fired ZTA material after sinter forging.

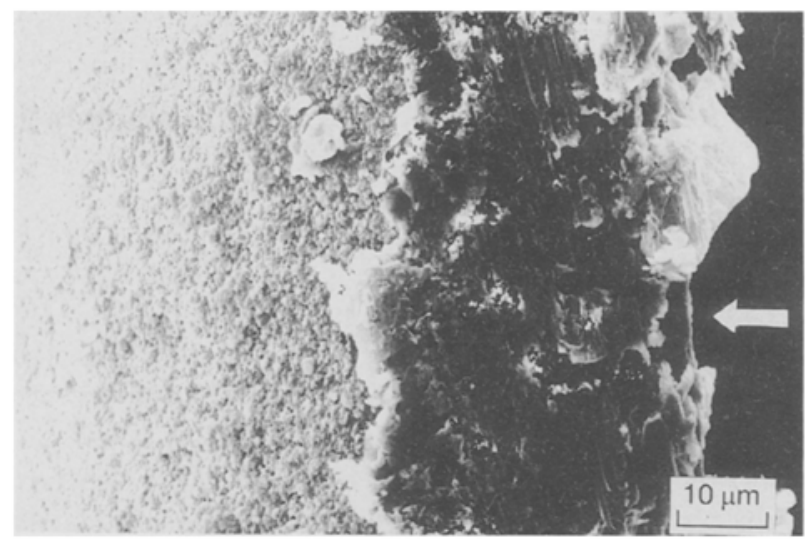

Figure 10 SEM of the fracture surface of ZTA ceramic after sinter forging at $1450^{\circ} \mathrm{C}$ for $15 \mathrm{~min}$ and $40 \mathrm{MPa}$. A porous layer is present on the top surface (indicated by an arrow).

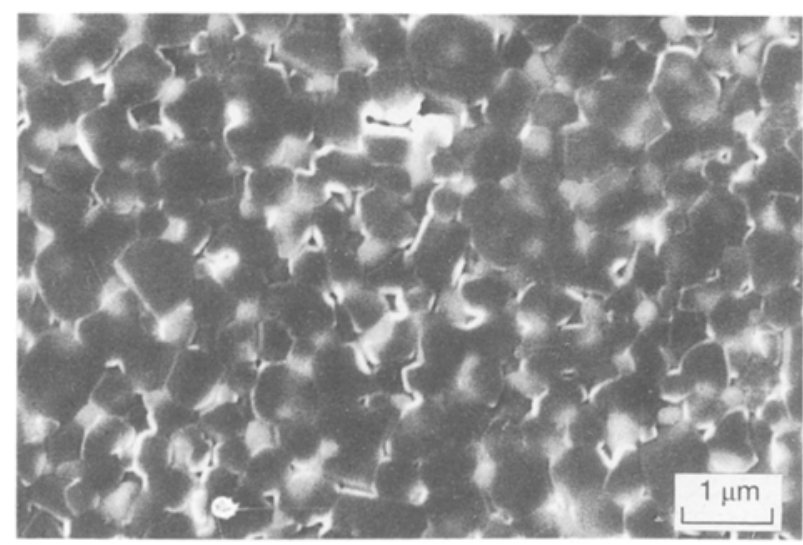

Figure 11 SEM of the surface layer after the as-fired surface is polished out $60 \mu \mathrm{m}$ in sinter forged ZTA materials.

$60 \mu \mathrm{m}$ depth, a pore-free area is observed (Fig. 11). It is necessary to remove this porous surface layer completely in order to have a ZTA material with an improved strength and toughness [23].

\section{Conclusions}

Alumina-15 wt \% undoped zirconia ceramics (ZTA) were investigated, in which powders were prepared by a coprecipitation method and calcined at 900 and $1100^{\circ} \mathrm{C}$.

1. A homogeneous microstructure with an alumina grain size of $0.7 \mu \mathrm{m}$ and a zirconia grain size of $0.2 \mu \mathrm{m}$ is achieved after sinter forging at $1400^{\circ} \mathrm{C}$ for $15 \mathrm{~min}$.

2. The large effective shear strain up to 0.8 effectively eliminate flaws and pores in compacts and result in complete dense ZTA ceramics after sinter forging at $1400^{\circ} \mathrm{C}$ for $15 \mathrm{~min}$.

3. Sinter forging is an effective technique to shift the temperature of densification of these ZTA materials to lower temperature, compared with pressureless sintering. During sinter forging, the densification behaviour is independent on the calcination temperatures of the ZTA powders. The intraaggregate pores present in the compact calcined at $900^{\circ} \mathrm{C}$ disappear prior to the phase transformation to $\alpha$ alumina due to particle rearrangement induced by the applied pressure. 
4. The applied compressive stress causes the $\theta$ to $\alpha$ alumina transformation to occur at lower temperature. This decrease due to the applied pressure is independent on the proceeding calcination temperature.

\section{Acknowledgements}

The authors would like to thank Ing. P. M. V. Bakker for performing the nitrogen adsorption-desorption measurements. CMO at University of Twente is acknowledged for performing SEM and TEM analysis. This research was partly supported by the Innovative Research Program on Technical Ceramics (IOP-TK) with financial aid from the Dutch Ministry of Economic Affairs.

\section{References}

1. K. R, VEnkAtaChARI and R. RAJ, J. Amer. Ceram. Soc. 70 (1987) 514.

2. M. N. RAHAMAN and L. C. DE JONGHE, ibid. 69 (1986) 53.

3. F. F. LANGE, ibid. 66 (1983) 396.

4. F. F. LANGE and M. METCALF, ibid. 66 (1983) 398.

5. A. G. EVANS, ibid. 65 (1982) 497.

6. KEIZO UEMATSU, MASAYORI MIYASHITA, JIN YOUNG KIM and NOZOMU UCHIDA, ibid. 75 (1992) 1016.

7. A. J. A. WINNUBST, W. F. M. GROOT ZEVERT, G. S. A. M. THEUNISSEN and A. J. BURGGRAAF, Mater. Sci. Engng A109 (1989) 215.

8 J. S. REED, T. CARBONE, C. SCOTT and S. LUKASIEWICZ, in "Processing of Crystalline Ceramics," edited by H. Palmour III, R. F. Davis and T. M. Hare (Plenum, New York, 1978) pp. 171-80.

9. KOJI TSUKUMA and KUNIYOSHI UEDA, J. Amer. Ceram. Soc. 68 (1985) C4

10. K. NAKAJIMA and T. MASAKI, "Advanced in Ceramics". Vol. 24B, Science and Technology of Zirconia III, edited by
S. Sōmiya, N. Yamamoto and H. Hanagida, (American Ceramics Society, Columbus, OH, 1988) pp. 625-633.

11. N. CLA USSEN and J. JAHN, J. Amer. Ceram. Soc. 61 (1978) 94.

12. G. ORANGE, G. FANTOZZI, P. HOMERIN, F. THEVENOT, A LERICHE and F. CAMBIER, "Advances in Ceramics." Vol. 24B, Science and Technology of Zirconia III, edited by S. Sōmiya, N. Yamamoto and H. Hanagida, (American Ceramic Society, Columbus, OH, 1988) pp. 1075-1082.

13. B. J. Kellet T and F. F. LANGe, J. Amer. Ceram. Soc. 69 (1986) C172.

14 P. C. PANDA, J. WANG and R. RAJ, ibid. 71 (1988) C507.

15. K. R. VENKATACHAR and R. RAJ, ibid. 69 (1986) 499.

$16 \mathrm{M}$. M. R. BOUTZ, A. J. A. WINNUBST, A. J. BURGGRAAF, M. NAUER and C. CARRY, ibid. accepted (1994).

17. P. DEN EXTER, A. J. A. WINNUBST and A. J. BURGGRAAF, ibid. accepted (1994).

18 H. TORAYA, M. YOSHIMURA and S. SŌMIYA, ibid. 67 (1984) C119.

19. J. C. WURST and J. A. NELSON, ibid. 55 (1972) 109.

20. J. H. DE BOER, in "The Structure and Properties of Materials", edited by D. H. Evertett and F. S. Stone (Butterworth, London, 1985), pp. 68-94.

21. D. C. HAGUE and M. J. MAYO, "Mechanical Properties and Deformation Behaviour of Materials Having Ultra-Fine Microstructures", ASI Series E, Applied Sciences Vol. 233 Edited by M. Nastasi, D. M. Parkin and H. Gleiter, (NATO, 1992) pp. 539-545.

22. R. R. WILLS and J. K. McCOY, J. Amer. Ceram. Soc. 68 (1985) C95.

23. Y. J. HE, A. J. A. WINNUBST, H. VERWEIJ and A. J. BURGGRAAF, J. Mater. Sci. accepted (1994).

24. A. H. HEUER, D. J. SELLERS and W. H. RHODES, J Amer. Ceram. Soc. 52 (1969) 468.

25. Y. MA and K. J. BOWMAN, ibid. 74 (1991) 2941.

26. K. TSUK UMA and M. ShIMAOA, Amer. Ceram. Soc. Bull. 64 (1985) 310.

Received 9 September 1993 and accepted 16 May 1994 